Available online at https://www.irjst.com/
International Research Journal of Science and Technology
ISSN:2707-3955
DOI: https://doi.org/10.46378/irjst.2020.010211

\title{
The influence of Deposition Temperature on the Properties of Chemically Sprayed Nanostructured $\mathrm{Cu}_{2} \mathrm{CdSnS}_{4}$ Thin Films
}

\author{
Hiba J. Ahmed, Asaad A. Kamil, Ammar A. Habeeb, Nabeel A. Bakr* \\ Department of Physics, College of Science, University of Diyala, Diyala, Iraq
}

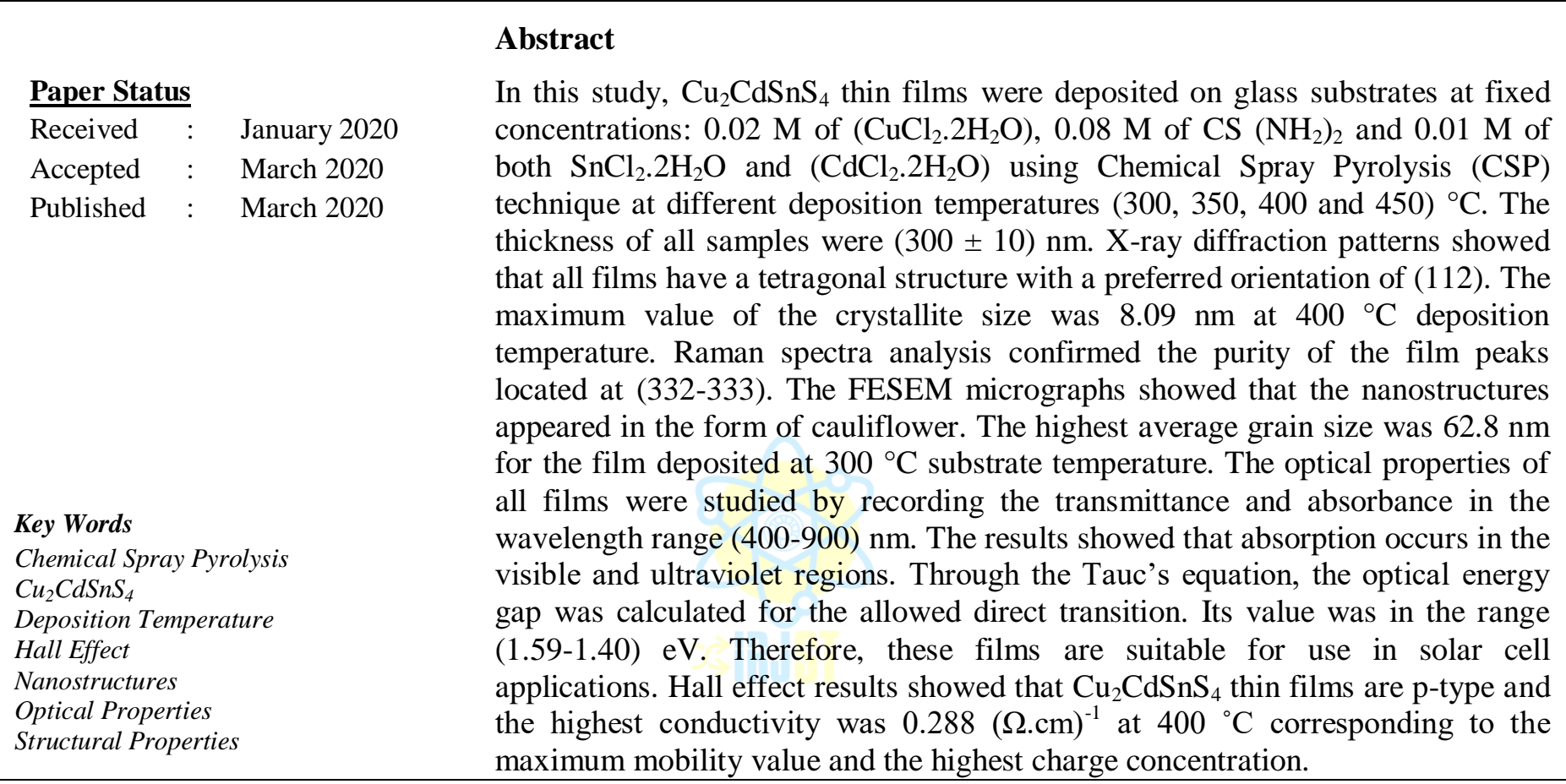

Copyright ( ) 2020: Hiba J. Ahmed, Asaad A. Kamil, Ammar A. Habeeb, Nabeel A. Bakr. This is an open access distribution, and reproduction in any medium, provided Access article distributed under the Creative Commons Attribution License the original work is properly cited License, which permits unrestricted use.

Citation: Hiba J. Ahmed, Asaad A. Kamil, Ammar A. Habeeb, Nabeel A. Bakr. "The influence of Deposition Temperature on the Properties of Chemically Sprayed Nanostructured $\mathrm{Cu}_{2} \mathrm{CdSnS}_{4}$ Thin Films". International Research Journal of Science and Technology, 1 (2), 149-155, 2020.

\section{Introduction}

In recent years, there has been a great deal of interests in research field of chalcopyrite semiconductors due to their suitable band gaps and high optical absorption coefficient for potential application in thin film solar cells $[1,2]$. Recently, higher power conversion efficiencies of solar cells based on $\mathrm{Cu}_{2} \mathrm{ZnSnS}_{4}$ and $\mathrm{Cu}_{2} \mathrm{ZnSn}(\mathrm{S}, \mathrm{Se})_{4}$ as high as $8.4 \%$ and $10.1 \%$ have been reported $[3,4]$.

*Corresponding Author: Nabeel A. Bakr

Department of Physics, College of Science

University of Diyala, Diyala, Iraq.

Email : nabeelalibakr@yahoo.com
Because $\mathrm{Cu}_{2} \mathrm{CdSnS}_{4}$ structure is similar to $\mathrm{Cu}_{2} \mathrm{ZnSnS}_{4}$ and has a band gap of $1.37 \mathrm{eV}$ and a large absorption coefficient $10^{4} \mathrm{~cm}^{-1}, \mathrm{Cu}_{2} \mathrm{CdSnS}_{4}$ is also considered as possible photovoltaic material $[1,2]$. Chemical spray pyrolysis technique has attracted many research groups to prepare different types of thin film materials because it is considered as a low-cost technique compared with other methods which usually require high-cost devices and complex instrumentation such as vacuum systems. Furthermore, it does not require high quality targets or substrates and can be easily scaled up for industrial applications [3]. In the current study, the structural, optical and electrical properties of $\mathrm{Cu}_{2} \mathrm{CdSnS}_{4}$ thin films deposited by chemical spray pyrolysis technique at different deposition temperatures are reported. 


\section{Experimental Details}

$\mathrm{Cu}_{2} \mathrm{CdSnS}_{4}$ thin films were deposited on soda lime glass substrates by chemical spray pyrolysis. The substrates were cleaned ultrasonically in distilled water, acetone for $(10 \mathrm{~min})$ and then dried by air. The solution was prepared by mixing aqueous solutions of copper chloride dihydrate $\left(\mathrm{CuCl}_{2} .2 \mathrm{H}_{2} \mathrm{O}\right)(0.08524 \mathrm{~g}$ in $25 \mathrm{ml})$, cobalt chloride dihydrate $\left(\mathrm{CdCl}_{2} \cdot 2 \mathrm{H}_{2} \mathrm{O}\right)$ $(0.0564 \mathrm{~g}$ in $25 \mathrm{ml})$, tin chloride dihydrate $\left(\mathrm{SnCl}_{2} .2 \mathrm{H}_{2} \mathrm{O}\right)(0.0503 \mathrm{~g}$ in $25 \mathrm{ml})$ and thiourea $\left(\mathrm{SC}\left(\mathrm{NH}_{2}\right)_{2}\right)(0.1522 \mathrm{~g}$ in $25 \mathrm{ml})$. The solutions were mixed by magnetic stirrer and left for few. The spray process was done using a homemade system at different substrate temperatures of $(300,350,400$ and 450) ${ }^{\circ} \mathrm{C}$. The deposition conditions are described elsewhere [5]. The prepared films have good adhesive properties with a uniform thickness of $(300 \pm 10) \mathrm{nm}$ estimated by gravimetric method. The structural properties were investigated by using Grazing Incidence X-Ray Diffraction (GIXRD) (Ultima IV XRay diffractometer) with $\mathrm{CuK} \alpha$ radiation $(\lambda=1.5406$ $\AA)$ as the source. Topography of the surface of the deposited films was imaged using FESEM (MIRA3, TE-SCAN). Raman spectra were recorded at backscattering configuration using (Jobin-Yvon Horiba Labram800). The optical transmission and absorption spectra of the films were recorded by (Shimadzu, UV- 1800) in the wavelength range of (350-900) nm. Hall effect measurements were conducted by using (Ecopia HMS 3000).

\section{Results and Discussion}

The results of the X-ray diffraction test of $\mathrm{Cu}_{2} \mathrm{CdSnS}_{4}$ thin films prepared at different substrate temperatures $\left(300,350,400\right.$ and 450) ${ }^{\circ} \mathrm{C}$ are shown in Figure 1 and Table 1. The results show that the patterns possess many peaks with a clear peak at $\left(2 \theta \approx 28^{\circ}\right)$ corresponding to the direction (112). These results match well the data of ICDD card number (29-0537) which shows peak locations at $\left(2 \theta=28.29^{\circ}, 47.12^{\circ}\right.$, $56.102^{\circ}, 68.366^{\circ}, 32.728^{\circ}, 69.229^{\circ}$ ) $[4,6]$. The intensity of the peaks of these films increases with increasing the temperature of the substrate, and this indicates the increase in the crystallization and the reduction of crystal defects. Note that there are no peaks for secondary phases such as binary and high compounds $\left(\mathrm{Cu}_{2} \mathrm{~S}, \mathrm{SnS}, \mathrm{Cu}_{2} \mathrm{SnS}_{4}, \mathrm{CdSnO}_{3}\right)$. It can be also observed that the peak in the direction (112) is more prominent than its peers and this is due to the effect of deposition temperature on the growth in this direction [7]. The volume of the unit cell of all samples prepared was smaller than the standard volume $\left(326.51 \AA^{3}\right)$, where the unit cell suffered stress. The values of the lattice constant for the films are consistent with the values found in the standard card no. of the material which is $(a=5.487 \AA$ and $c=10.84 \AA)$. The estimated values of c/a of all samples are greater than that of the standard value (1.976) which indicates that the unit cell is elongated along the c-direction. The crystallite size of the samples was estimated using the wellknown Scherrer's formula [8]:

$$
D=\frac{0.9 \lambda}{\beta \cos \theta}
$$

Where $\mathrm{D}$ is the crystallite size, $\beta$ is the full width at half maximum (FWHM), $\lambda$ is the X-ray wavelength of $\mathrm{CuK} \alpha$ and $\theta$ is the Bragg's angle. The increase in the size of the crystals is due to the increase in temperature, which leads to an increase in the kinetic energy of the arranged atoms, which makes it easier for them to work in their correct locations in the crystal network. The highest crystallite size was 8.09 $\mathrm{nm}$ for the sample deposited at $400{ }^{\circ} \mathrm{C}$. The low crystallite size is likely to be present in nanostructures [9]. The texture coefficient (Tc) was calculated using equation (2) describing the predominant trend of prepared films (112) as shown in Table 1 [10].

$$
T_{c(h k l)}=\frac{I_{(h k l)} / I_{o(h k l)}}{N_{r}^{-1} \sum I_{(h k l)} / I_{o(h k l)}}
$$

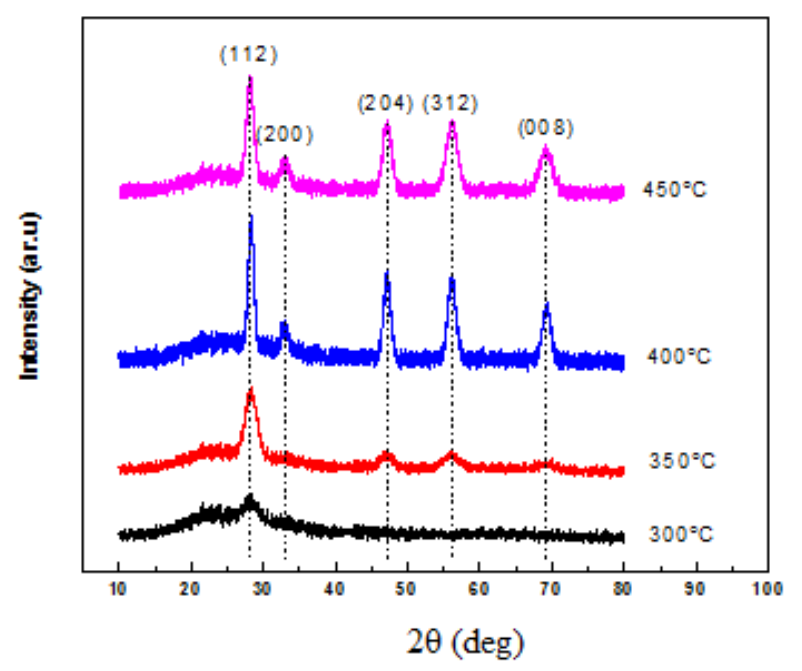

Figure 1. X-ray diffraction patterns of $\mathrm{Cu}_{2} \mathrm{CdSnS}_{4}$ thin films.

The obtained Raman spectra shown in Figure 2 confirm the formation of $\mathrm{Cu}_{2} \mathrm{CdSnS}_{4}$ with purified stannite phase of all prepared film samples. The recorded spectra for the samples shown in black color were analyzed using the origin pro.8.5 program, where several peaks were obtained (green color), one of which is the main peak $(332-333) \mathrm{cm}^{-1}$, and the others are located at $(328,250,253,283,350$ and 353$) \mathrm{cm}^{-1}$ $[4,6]$ as shown in Table 2. 
The results of Raman spectra shown are fully consistent with the results of X-ray diffraction, though; they often complement each other and strongly confirm that $\mathrm{Cu}_{2} \mathrm{CdSnS}_{4}$ films in the pure phase free from the secondary phases.

Table 1. X-ray diffraction results of the CCTS thin films.

\begin{tabular}{lllll}
\hline Deposition Temperature $\left({ }^{\circ} \mathrm{C}\right)$ & 300 & 350 & 400 & 450 \\
\hline $\mathrm{hkl}$ & 112 & 112 & 112 & 112 \\
$2 \theta($ deg.) & 28.22 & 28.28 & 28.30 & 28.24 \\
$\mathrm{~d}_{\text {hkl }}(\AA)$ & 3.16 & 3.15 & 3.15 & 3.16 \\
FWHM (deg.) & 1.39 & 2.27 & 1.06 & 1.35 \\
Lattice constant (a) $(\AA)$ & 5.40 & 5.46 & 5.46 & 5.45 \\
Lattice constant (c) $(\AA)$ & 10.80 & 10.88 & 10.85 & 10.86 \\
c/a & 2.000 & 1.993 & 1.987 & 1.993 \\
Unit Cell Volume $\left(\AA^{3}\right)$ & 314.928 & 324.350 & 323.456 & 322.569 \\
$\mathrm{D}(\mathrm{nm})$ & 6.30 & 3.61 & 8.09 & 6.33 \\
$\mathrm{~T}_{\mathrm{ch}(\mathrm{hkl})}$ & 1.12 & 1.33 & 1.22 & 1.20 \\
\hline
\end{tabular}

Table 2. Results of Raman analysis.

\begin{tabular}{llll}
\hline $\begin{array}{l}\text { Deposition } \\
\begin{array}{l}\text { Temperature } \\
\left({ }^{\circ} \mathrm{C}\right)\end{array}\end{array}$ & $\begin{array}{l}\text { Center } \\
\text { of Peak } \\
\left(\mathrm{cm}^{-1}\right)\end{array}$ & $\begin{array}{l}\text { Width } \\
\text { of Peak } \\
\left(\mathrm{cm}^{-1}\right)\end{array}$ & $\begin{array}{l}\text { Intensity } \\
(\text { a.u. })\end{array}$ \\
\hline 300 & 283 & 10.89 & 3.90 \\
& 333 & 16.05 & 60.01 \\
\hline \multirow{3}{*}{350} & 328 & 8.10 & 7.17 \\
& 332 & 5.03 & 70.13 \\
& 353 & 8.81 & 2.91 \\
\hline \multirow{3}{*}{400} & 250 & 4.39 & 2.84 \\
& 283 & 6.14 & 9.92 \\
& 333 & 5.00 & 99.88 \\
& 353 & 7.21 & 4.11 \\
\hline \multirow{3}{*}{450} & 250 & 4.52 & 2.28 \\
& 283 & 9.77 & 8.02 \\
& 333 & 7.00 & 80.11 \\
\hline
\end{tabular}

The morphology of the prepared thin films was studied using FESEM, which depicts the surfaces in high magnification and high resolution $(50 \mathrm{KX})$. The images of $\mathrm{Cu}_{2} \mathrm{CdSnS}_{4}$ thin films prepared at different deposition temperatures are shown in Figure 3. It can be observed that the prepared $\mathrm{Cu}_{2} \mathrm{CdSnS}_{4}$ thin films have cauliflower-like forms with an irregular particle sizes and have some cracks and voids resulting from crystalline defects with secondary growth on the surface and this means the growth of a new layer before the completion of the previous layer $[11,12]$. The average grain size values of all samples are shown in Table 3.
Figure 4 shows the absorption coefficient as a function of the wavelength of the $\mathrm{Cu}_{2} \mathrm{CdSnS}_{4}$ thin films. The obtained results showed high values of the absorption coefficient $\left(\alpha>10^{4} \mathrm{~cm}^{-1}\right)$ in the visible spectrum and ultraviolet, indicating a high probability of direct electronic transitions. The energy gap value of direct electronic transitions was calculated by plotting a graphical relationship of $(\alpha h v)^{2}$ versus photon energy (hv) and taking the best straight portion after the fundamental absorption edge to intersect the photon energy at $\left((\alpha h v)^{2}=0\right)$ as shown in Figure 5. The energy gap values for the $\mathrm{Cu}_{2} \mathrm{CdSnS}_{4}$ films was found to be in the range of (1.59-1.40) eV as shown in Table 4 which 

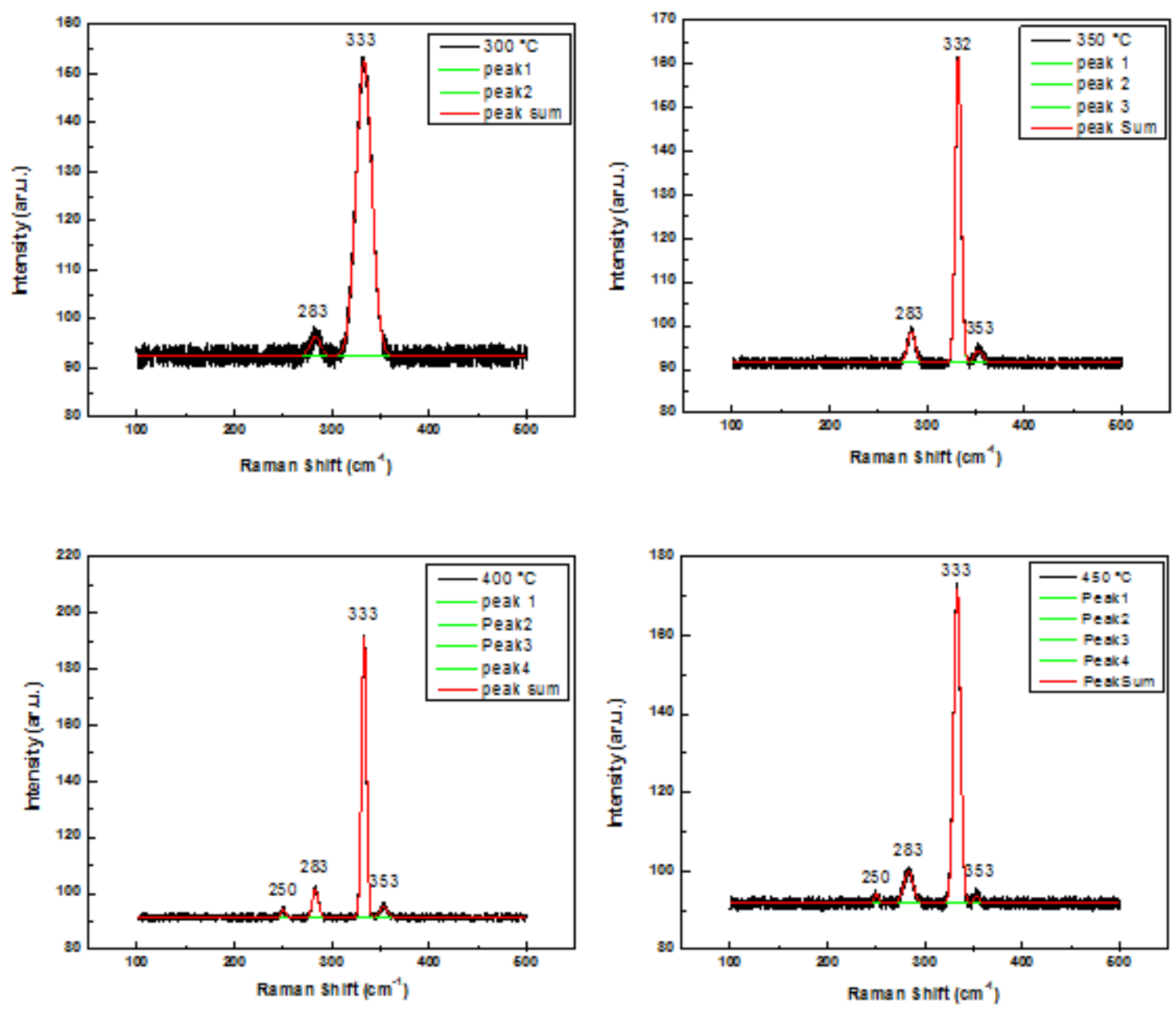

Figure 2. Raman spectra of $\mathrm{Cu}_{2} \mathrm{CdSnS}_{4}$ thin films under test.
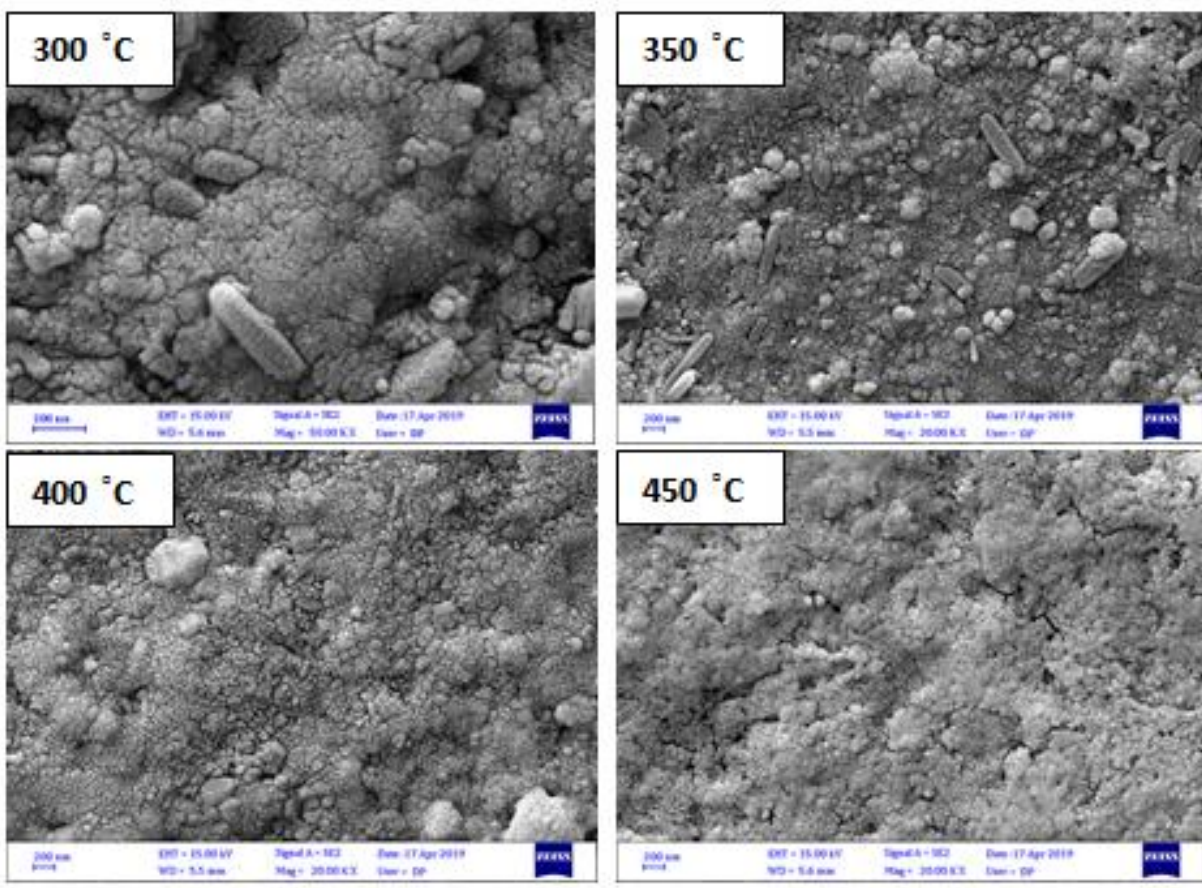

Figure 3. FESEM images of $\mathrm{Cu}_{2} \mathrm{CdSnS}_{4}$ thin films under test. 
Table 3. Average grain size of $\mathrm{Cu}_{2} \mathrm{CdSnS}_{4}$ thin films.

\begin{tabular}{ll}
\hline $\begin{array}{l}\text { Deposition } \\
\text { Temperature }\left({ }^{\circ} \mathrm{C}\right)\end{array}$ & $\begin{array}{l}\text { Average } \\
\text { Grain Size }(\mathrm{nm})\end{array}$ \\
\hline 300 & 62.8 \\
350 & 61.1 \\
400 & 52.9 \\
450 & 54.2 \\
\hline
\end{tabular}

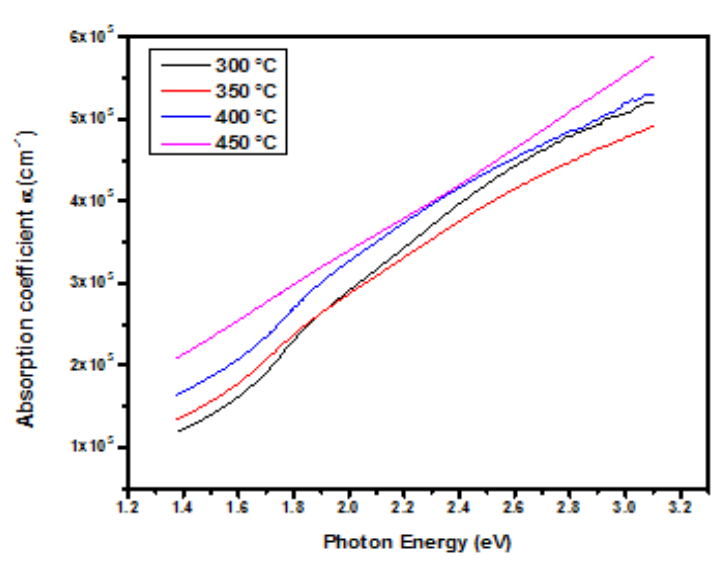

Figure 4. The relationship between the absorption coefficient and the photon energy of $\mathrm{Cu}_{2} \mathrm{CdSnS}_{4}$.
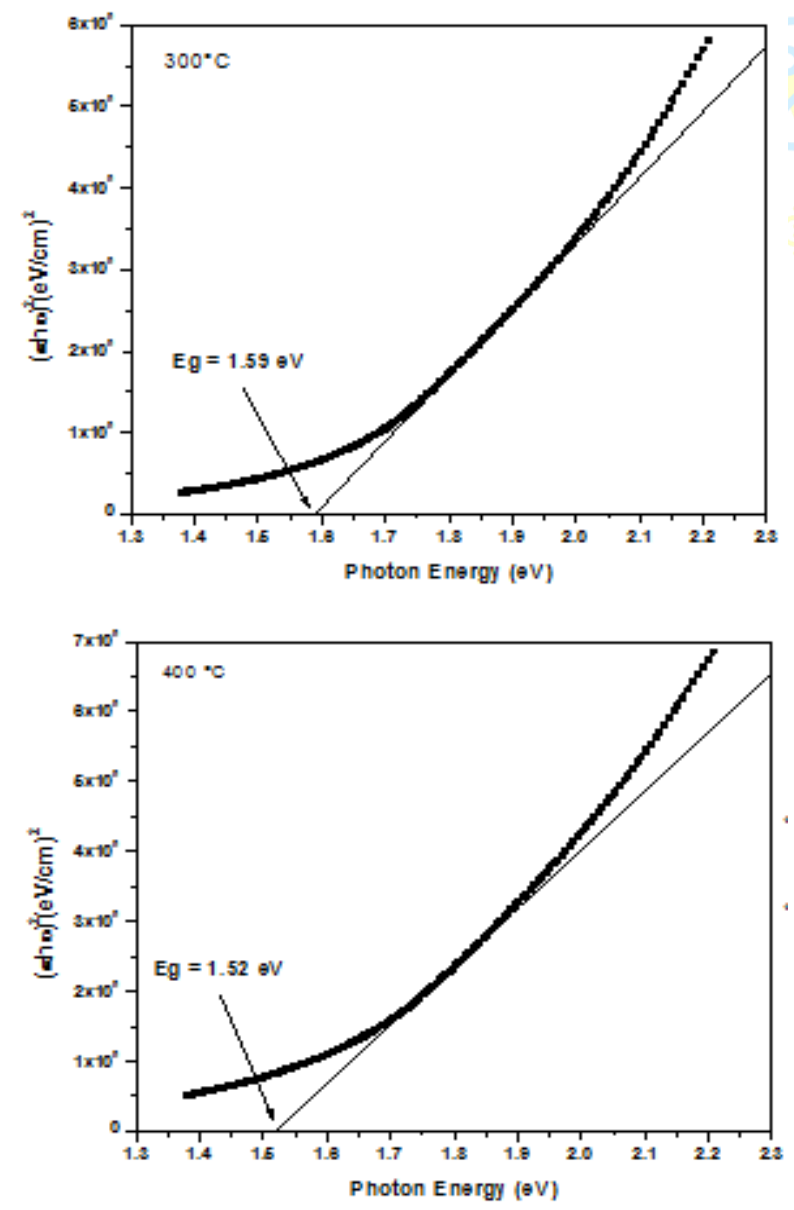

Figure 5a. The relation between $(\alpha h v)^{2}$ and (hv) for $\mathrm{Cu}_{2} \mathrm{CdSnS}_{4}$ thin films. agrees well with results reported by previous studies [13-15]. These values are very close to those used for solar cell applications. The energy gap values depend on the crystalline structure in general and are affected by the increase in deposition temperature which is consistent with previous reports [11, 16-18].
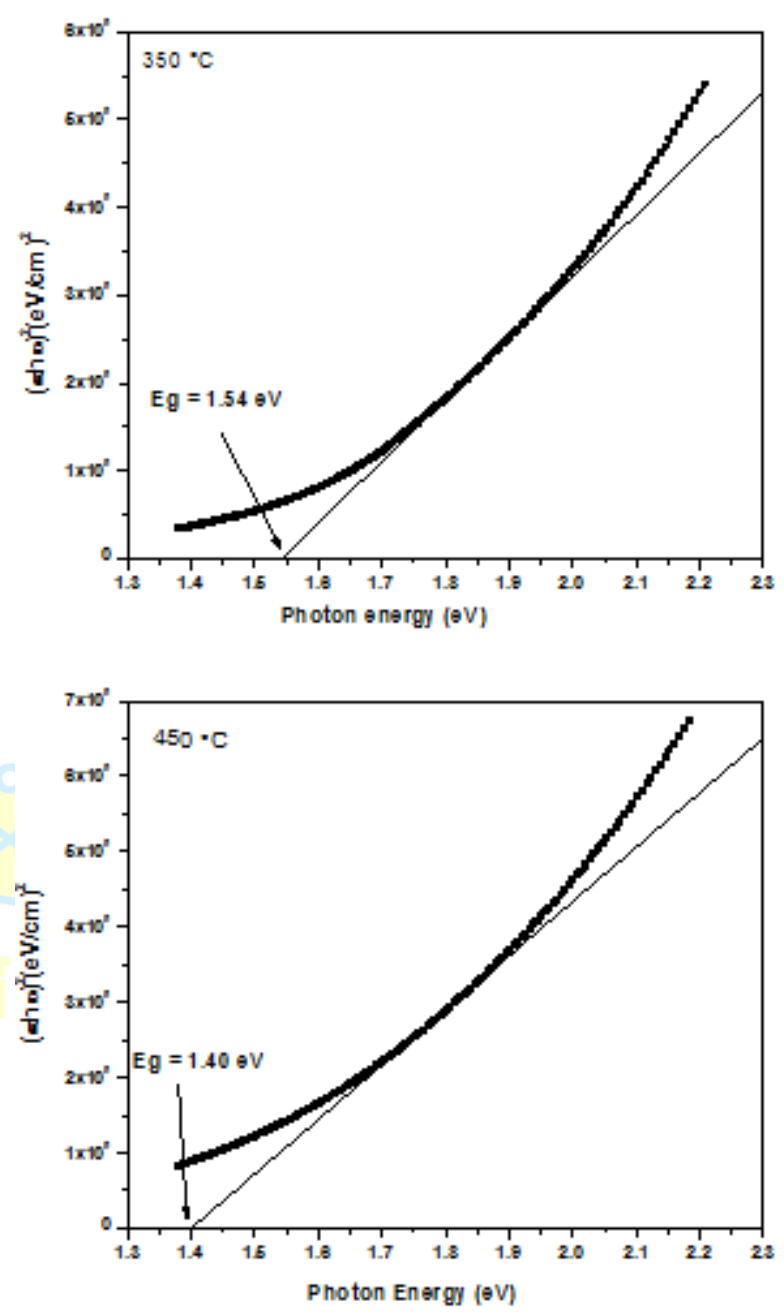

Figure $5 \mathrm{~b}$. The relation between $(\alpha \mathrm{h} v)^{2}$ and $(\mathrm{h} v)$ for $\mathrm{Cu}_{2} \mathrm{CdSnS}_{4}$ thin films.

Table 4. Values of optical energy band gap of $\mathrm{Cu}_{2} \mathrm{CdSnS}_{4}$

\begin{tabular}{ll}
\multicolumn{2}{c}{ thin films. } \\
\hline $\begin{array}{l}\text { Substrate } \\
\text { Temperature }\left({ }^{\circ} \mathrm{C}\right)\end{array}$ & $\mathrm{E}_{\mathrm{g}}(\mathrm{eV})$ \\
\hline 300 & 1.59 \\
350 & 1.54 \\
400 & 1.52 \\
450 & 1.49 \\
\hline
\end{tabular}


Table $5 \mathrm{a}$ and $\mathrm{b}$ shows the results of Hall Effect measurements. The highest electrical conductivity value was found to be $0.288(\Omega . \mathrm{cm})^{-1}$ for the film deposited at $400{ }^{\circ} \mathrm{C}$ and the highest mobility for charge carriers was $2.334\left(\mathrm{~cm}^{2} / \mathrm{V} . \mathrm{s}\right)$ for the same sample. The sign of Hall coefficient is positive which indicates that majority carriers are holes. Carrier concentration reaches its maximum value $7.71 \times 10^{17}\left(\mathrm{~cm}^{-3}\right)$ for the sample deposited at $400{ }^{\circ} \mathrm{C}$, which means that crystal growth has been completed [19].

Table 5. Results of Hall effect measurements.

\begin{tabular}{llllll}
\hline $\begin{array}{l}\text { Deposition } \\
\text { Temperature }\left({ }^{\circ} \mathrm{C}\right)\end{array}$ & $\begin{array}{l}\mathrm{R}_{\mathrm{H}} \\
\left(\mathrm{cm}^{3} / \mathrm{C}\right)\end{array}$ & $\begin{array}{l}\mathrm{n} \\
\left(\mathrm{cm}^{-3}\right)\end{array}$ & $\begin{array}{l}\mu \\
\left(\mathrm{cm}^{2} / \mathrm{V} . \mathrm{s}\right)\end{array}$ & $\boldsymbol{\rho}(\Omega . \mathrm{cm})$ & $\begin{array}{l}\boldsymbol{\sigma} \\
(\Omega . \mathrm{cm})^{-1}\end{array}$ \\
\hline 300 & 22.533 & $2.77 \times 10^{17}$ & 0.323 & 69.71 & 0.0143 \\
350 & 14.755 & $4.23 \times 10^{17}$ & 0.981 & 15.041 & 0.0664 \\
400 & 8.095 & $7.71 \times 10^{17}$ & 2.334 & 3.468 & 0.2883 \\
450 & 10.199 & $6.12 \times 10^{17}$ & 1.711 & 5.961 & 0.167 \\
\hline
\end{tabular}

\section{Conclusions}

In this study, nanostructured $\mathrm{Cu}_{2} \mathrm{CdSnS}_{4}$ thin films were prepared by the chemical spray pyrolysis method at different substrate temperatures. From XRD and Raman analysis it was concluded that $\mathrm{Cu}_{2} \mathrm{CdSnS}_{4}$ films possess tetragonal structure having a stannite phase with a preferred orientation (112). All films are P-type. The substrate temperature $400{ }^{\circ} \mathrm{C}$ is distinguished by having the best structural, electrical and optical properties. The properties of the prepared films suggest that they can be a good candidate for absorbent layer in solar cells.

\section{References}

[1]. Guan $\mathrm{H}$, Zhao J, Wang X, Yu F. $\mathrm{Cu}_{2} \mathrm{CdSnS}_{4}$ thin film prepared by a simple solution method. Chalcogenide Lett. 2013;10(10).

[2]. Rouchdi M, Salmani E, Hassanain N, Mzerd A. Effect of deposition time on structural and physical properties of $\mathrm{Cu} 2 \mathrm{CdSnS} 4$ thin films prepared by spray pyrolysis technique: experimental and ab initio study. Optical and Quantum Electronics. 2017;49(4):165.

[3]. Patil PS. Versatility of chemical spray pyrolysis technique. Materials Chemistry and physics. 1999; 15;59(3):185-98.

[4]. Filipovic L, Selberherr S, Mutinati GC, Brunet E, Steinhauer S, Köck A, Teva J, Kraft J, Siegert J, Schrank F. Methods of simulating thin film deposition using spray pyrolysis techniques. Microelectronic Engineering. 2014; 117:57-66.

[5]. Bakr NA, Salman SA, Hameed SA. Deposition and Characterization of $\mathrm{Cu} 2 \mathrm{ZnSnS} 4$ Thin Films for Solar Cell Applications, International Journal of Applied Engineering Research 13(6):3379-88, (2018

[6]. Maldar PS, Gaikwad MA, Mane AA, Nikam SS, Desai SP, Giri SD, Sarkar A, Moholkar AV. "Fabrication of Cu2CoSnS4 thin films by a facile spray pyrolysis for photovoltaic application." Solar Energy158 (2017): 89-99.
[7]. W. Daranfed, M. S. Aido, A. Hafdallah and H. Lekiket. "Substrate temperature influence on $\mathrm{ZnS}$ thin films prepared by ultrasonic spray." Thin Solid Films 518.4 (2009): 1082-1084.

[8]. Bakr NA, Khodair ZT, Mahdi HI. Influence of thiourea concentration on some physical properties of chemically sprayed $\mathrm{Cu} 2 \mathrm{ZnSnS} 4$ thin films. International Journal of Materials Science and Application. 2016;5(6):261-70.

[9]. Benchikri M, Zaberca O, El Ouatib R, Durand B, Oftinger F, Balocchi A, Chane-Ching JY. "A high temperature route to the formation of highly pure quaternarychalcogenide particles." Materials Letters68 (2012): 340-343.

[10]. [Ahmed M, Bakr N, Kamil A. Synthesis and characterization of chemically sprayed $\mathrm{Cu} 2 \mathrm{CoSnS} 4$ Thin Films. Chalcogenide Letters. 2019 May;16(5):231-9.

[11]. Pawlikowski, J. M. "Preparation and characterization of close-spaced vapour transport thin films of $\mathrm{ZnSe}$ for heterojunction solar cells." Thin Solid Films 127.1-2 (1985): 9-28.

[12]. W. Daranfed, M. S. Aido, and H. Lekiket, "Temperature dependent properties of spray deposited $\mathrm{Cu} 2 \mathrm{CoSnS} 4 \quad$ (CCTS) thin films." Journal of Materials Science: Materials in Electronics 28.24 (2017): 18891-18896.

[13]. Zhang, Zhenyu, and Max G. Lagally. "Atomistic processes in the early stages of thin-film growth." Science 276.5311 (1997): 377-383.

[14]. Dong YJ, Gao YL. Structural, Mechanical and Thermodynamic Properties of Cu2CoXS4 (X=Si, Ge, Sn) Studied by Density Functional Theory. Semiconductors. 2018 Apr 1;52(4):414-9.

[15]. Huang KL, Huang CH, Lin WT, Fu YS, Guo TF.. "Solvothermal synthesis and tunable bandgap of $\mathrm{Cu} 2(\mathrm{Zn} 1-\mathrm{xCox}) \mathrm{SnS} 4$ and $\mathrm{Cu} 2(\mathrm{Fe} 1-\mathrm{xCox}) \mathrm{SnS} 4$ nanocrystals." Journal of Alloys and Compounds 646 (2015): 1015-1022.

[16]. Balasubramanian, V., P. Naresh Kumar, and D. Sengottaiyan. "Effect of deposition temperature 
on structural, optical and electrical properties of copper bismuth sulphide (CuBiS2) thin films deposited by chemical bath deposition." Materials Science-Poland 35.2 (2017): 329-334.

[17]. Meng, Li-jian, and M. P. Dos Santos. "Properties of indium tin oxide films prepared by rf reactive magnetron sputtering at different substrate temperature." Thin Solid Films 322.1-2 (1998): 56-62.

[18]. Bakr NA, Khodair ZT, Hassan SM. Effect of substrate temperature on structural and optical properties of $\mathrm{Cu} 2 \mathrm{ZnSnS} 4$ (CZTS) films prepared by chemical spray pyrolysis method. Research Journal of Chemical Sciences ISSN. 2015;2231:606X.

[19]. Sarkar S, Howli P, Das B, Das NS, Samanta M, Das GC, Chattopadhyay KK. Novel quaternary chalcogenide/reduced graphene oxide-based asymmetric supercapacitor with high energy density. ACS applied materials \& interfaces. 2017 Jun 28;9(27):22652-64. 